\title{
Biogenesis of mitochondria: genetic and molecular analysis of the oli2 region of mitochondrial DNA in Saccharomyces cerevisiae*
}

\author{
Charles E. Novitski, Ian G. Macreadie, Ronald J. Maxwell, H. B. Lukins, Anthony W. Linnane, and Phillip Nagley
}

Department of Biochemistry, Monash University, Clayton, Victoria 3168, Australia

Due to an error in the preparation of Fig. 3, the nucleotide sequence of the aapl gene that lies upstream of the oli2 gene was incorrectly shown. Nucleotide -813 was shown as $\mathrm{T}$; the correct nucleotide should be $\mathrm{C}$. Consequent upon this error was the designation of the 14th amino acid of the putative aap1 gene product as methionine; the correct amino acid should be threonine. In single letter code, the amino sequence of the aap1 gene product in the $r h o^{+}$strain J69-1B thus is as follows:

MPQLVPFYFMNQLTYGFLLMITLLILFSQFFLPMILRLYVSRLFISKL 